\title{
Effects of aquaculture on wild fish populations: a synthesis of data
}

\author{
Laura K. Weir and James W.A. Grant
}

\begin{abstract}
The potential adverse environmental effects of aquaculture have been the subject of considerable attention in both the media and the scientific literature. We undertook a synthesis of the published scientific literature, primarily concerning Atlantic salmon (Salmo salar), to assess the current data available regarding these potential effects. No data are available to test for the direct effects of aquaculture organisms on the demographics of wild fish populations. However, seven studies show that escaped salmon in the wild have lower fitness, as measured by survival and reproductive success, than native salmon. Thirteen other studies, encompassing 91 different traits, provide strong evidence of phenotypic differences between farmed and wild salmon, presumably because of artificial selection in the aquaculture environment. An additional 10 studies have documented significant genetic differences between farmed salmon and the wild fish with which they will interact, or potentially interact. Given the paucity of data regarding actual population consequences of escaped farmed fish on wild populations, and the documented differences between the two types of fish, it seems prudent to treat farmed fish as exotic species with potentially negative consequences for wild populations, particularly when the latter are of conservation concern.
\end{abstract}

Key words: aquaculture, Atlantic salmon, artificial selection, fitness, introgression.

Résumé : Les effets potentiellement néfastes de l'aquaculture sur l'environnement ont reçu beaucoup d'attention de la part des médias et dans la littérature scientifique. Les auteurs ont entrepris une synthèse de la littérature scientifique, surtout en ce qui concerne le saumon de l'Atlantique (Salmo salar), afin d'évaluer les données couramment disponibles, concernant ces effets potentiels. Il n'existe pas de données qui permettent de vérifier les effets directs des organismes en aquaculture, sur la démographie des populations de poissons sauvages. Cependant, sept études montrent que les saumons qui s'échappent des piscicultures sont moins bien adaptés, que les poissons indigènes, tel que mesuré par la survie et le succès de reproduction. Treize autres études, portant sur 91 caractères, démontrent l'existence de différences phénotypiques entre les saumons cultivés et les saumons sauvages, vraisemblablement attribuables aux conditions artificielles de l'aquaculture. Dix autres études font état de différences génétiques significatives entre les saumons de culture et les saumons sauvages, avec lesquels ils interagissent ou pourraient interagir. Compte tenu de la pauvreté des données concernant les conséquences des populations actuelles de poissons échappés

Received 13 June 2005. Accepted 7 September 2005. Published on the NRC Research Press Web site at http://er.nrc.ca/ on 1 November 2005.

L.K. Weir ${ }^{1,2}$ and J.W.A. Grant. Department of Biology, Concordia University, 7141 Sherbrooke Street West, Montréal, QC H4B 1R6, Canada.

${ }^{1}$ Corresponding author (e-mail: 1weir@dal.ca).

${ }^{2}$ Present Address: Department of Biology, Life Sciences Centre, Dalhousie University, Halifax, NS

B3H 4J1, Canada. 
de culture sur les populations sauvages, ainsi que des différences reconnues entre ces deux types de poissons, il semble prudent de traiter les poissons de culture comme des espèces exotiques, ayant des conséquences potentiellement négatives pour les populations sauvages, particulièrement lorsque ces espèces font l'objet de crainte pour leur conservation.

Mots clés : aquaculture, saumon de l'Atlantique, sélection artificielle, adaptation, introgression.

[Traduit par la Rédaction]

\section{Introduction}

The environmental effects of aquaculture have received considerable attention in the recent scientific literature (e.g., Folke et al. 1998; Naylor et al. 2000; Hites et al. 2004; Naylor et al. 2005). Of the many potential effects that aquaculture may have on ecosystems, our primary focus is the direct impact of escaped farmed aquatic organisms on wild populations. Because documenting population interactions is notoriously difficult (see Begon et al. 1996), a good fundamental knowledge about the species in question is imperative. Hence, we focus on the Atlantic salmon, Salmo salar, arguably the best studied of aquaculture organisms (e.g., Mather et al. 1998).

Escapes from aquaculture facilities have been reported throughout the Atlantic salmon's natural range and in areas where it has been introduced (Canada: Carr et al. 1997; McKinnell et al. 1997; McKinnell and Thomson 1997; Stokesbury and Lacroix 1997; Volpe et al. 2000; Stokesbury et al. 2001; Faroe Islands: Hansen et al. 1999; Hansen and Jacobsen 2003; Greenland: Hansen et al. 1997; England and Wales: Milner and Evans 2003; Iceland: Gudjonsson 1991; Ireland: Crozier 1993, 1998; Clifford et al. 1998; Poole et al. 2000; Norway: Gausen and Moen 1991; Lund et al. 1991; Lura and Sægrov 1991; Sægrov et al. 1997; Scotland: Webb et al. 1993; Youngson et al. 1993, Butler et al. 2005). As a result, escaped fish and wild individuals are likely to interact behaviourally, genetically, and ecologically. The outcome of these interactions may be affected by differences attributable to artificial and natural selection in different environments.

Artificial selection in aquaculture can lead to phenotypic changes in characters such as body size, composition, and age at sexual maturity (e.g., Gjerde 1984). As a consequence, it is almost certain that aquaculture organisms will differ genetically from those in the wild following direct and correlational selection for commercially desirable traits, as well as domestication selection caused by the farm environment. Changes in phenotype and genotype of farmed organisms can result in differences in fitness-related traits, which ultimately may alter the demographic structure of wild populations. In addition, the magnitude and direction of any changes in farmed populations will determine the degree to which they differ from those in the wild (Hutchings 1991). These potential differences become a concern for the maintenance of wild population size and structure if farmed fish enter the natural environment. As such, the extent of the effects of farmed fish on wild populations is contingent on a number of factors, including the population size of wild fish, the number and frequency with which farmed individuals enter the natural environment, and the degree of interbreeding between farmed and wild fish (Hutchings 1991).

Genetic effects of interbreeding on wild populations will depend on the extent of differentiation between farmed and wild populations. Local adaptation has been documented in salmonid species (reviewed by Taylor 1991), and genetic differentiation among Atlantic salmon populations between and within river systems occurs (Verspoor 1997). Thus, one expects differences among populations in fitness-related traits. However, artificial selection, as an extreme case of local adaptation, can cause rapid divergence of farmed populations from their wild counterparts, such that heritable characteristics may change significantly to accommodate the needs of industry (Gross 1998; Thorpe 2004). As such, introgression of genes from farmed fish may result in changes to behaviour and life history of invaded natural populations. However, behavioural interactions between farmed and wild fish can occur even in the absence of interbreeding. Direct competition for territories, food, and mates between farmed 
and wild fish can also affect natural populations. Furthermore, there may be indirect effects caused by differences with wild salmonids in predator avoidance and migratory behaviour.

Questions and concerns arising from the potential interactions between aquaculture and wild organisms have generated a number of qualitative and (or) predictive reviews on the subject (Windsor and Hutchinson 1990; Hindar et al. 1991; Hutchings 1991; Saunders 1991; Heggberget et al. 1993a; Jonsson 1997; McVicar 1997; Gross 1998; Youngson and Verspoor 1998; Youngson et al. 2001; Utter and Epifanio 2002; Naylor et al. 2005). The focus of our study is different. Herein, we conduct the first quantitative review of data in the published literature regarding interactions between farmed and wild salmonids, and summarize the available empirical evidence of the impact of farmed animals on organisms in the natural environment.

In our analysis of the literature, we classified results based on how directly they addressed the effects of aquaculture on populations of wild aquatic organisms. In decreasing order of importance, we categorized results as providing evidence of (or a lack thereof): (1) demographic effects of aquaculture on wild populations, (2) fitness differences between aquaculture and wild populations in simulated wild or wild conditions, (3) resource competition and predator avoidance in the wild between aquaculture and wild populations, (4) resource competition and predator avoidance in simulated-wild or laboratory conditions, (5) phenotypic and genetic differences between aquaculture and wild individuals and populations, (6) transfer of disease and parasites between aquaculture and wild populations, and (7) general impacts on ecosystems. Furthermore, we summarized the evidence by life stage to identify which life stages are potentially most affected by interactions with farmed individuals.

\section{Materials and methods}

Our analyses are based only on refereed publications regarding interactions between farmed and wild individuals. We have restricted our analysis to papers involving only organisms raised in aquaculture for the purpose of consumption, and excluded studies of hatchery fish, i.e., individuals raised for the purpose of wild population enhancement or preservation. We make the distinction between farmed and hatchery fish because farmed fish are likely experiencing more intense selection for commercial traits than hatchery fish (e.g., Einum and Fleming 2001). Furthermore, there is often some effort to ensure that hatchery fish of similar genetic origin, or those from similar habitats, are chosen for re-introduction into certain areas (Fleming and Petersson 2001). This is not generally the case for farmed fish, which are potentially derived from genetically different stocks than the wild populations they invade (e.g., Gjedrem et al. 1991). Thus, we define farmed fish as individuals raised primarily in aquaculture conditions mainly for human consumption.

Our analyses focus primarily on Atlantic salmon, because of the scarcity of data available for other species. Due to the broad range of experimental designs, approaches and analyses in the literature, we have taken a conservative approach to the analysis. Differences in life history and behaviour between farmed and wild fish were always based on within-study comparisons. We used molecular genetic studies to assess divergence of farmed populations from those in the wild. When significant differences were found in the original studies, only the direction of those differences was recorded. The percentage of observed differences was analysed using Binomial tests with an expected difference of $5 \%$ by chance alone. When significant differences were found, we used Sign tests to test for directional differences between farmed and wild fish. Directional differences were only tested for traits that could be related to fitness, allowing us to determine whether farmed fish were superior or inferior to wild fish for a given trait. Finally, we used goodness-of-fit tests to examine differences among life stages and phenotypic categories. We consider hybrids between farmed and wild fish to be farmed fish in the analyses. Inclusion of hybrids increased sample size and made the analyses more conservative. We also present the available data on parasite and disease transfer between farmed and wild organisms, though these data were not analysed statistically because studies of this type are scarce. The effects of aquaculture on communities 
and ecosystems surrounding aquaculture facilities are also discussed, but were not analysed due to the range of designs and study organisms that prevented any among-study comparisons.

\section{Results}

We first present the results in decreasing order of importance (i.e., regarding direct evidence of effects on wild populations), based on the categories identified in the Introduction (see Table 1 and Table A1) for 20 published studies that fit our criteria for analysis. Second, we summarize the overall results in two different ways. In the most conservative approach, we treat each of the 20 published studies as an independent datum. Next, for exploratory purposes, we treat each of the 178 traits measured in the 20 studies as an independent datum, which are summarized by life stage (i.e., juvenile freshwater, marine, and adult freshwater) and by phenotypic category (i.e., life history traits, adult behaviour, and juvenile behaviour).

\section{Demographic effects on populations}

Surprisingly, we found no published studies that have directly addressed the issue of whether or not farmed fish affect the density, size, or growth rate of wild fish populations.

\section{Fitness differences in simulated wild or wild conditions}

Only three studies (McGinnity et al. 1997, 2003; Fleming et al. 2000) have directly examined fitness differences between fish of farmed and wild origin in natural conditions over one or more generations. Five other studies, four in simulated natural conditions (Fleming et al. 1996; Garant et al. 2003; Weir et al. 2004, 2005) and one in the wild (Thorstad et al. 1998), measured some component of fitness over shorter time periods. These eight studies (see Table A1) provide evidence of fitness differences (i.e., survival and reproductive success) between farmed and wild fish. At least one component of fitness differed significantly in each study and a total of 28 out of 33 comparisons of traits related to fitness differed significantly between farmed and wild fish. Interestingly, survival and reproductive success were lower for farmed and hybrid fish than for wild fish in 22 of the 28 significant comparisons (Sign test: $P<0.01$; Table 1). Most notably, egg and juvenile survival, smolt output, and spawning success were generally lower for farmed than for wild fish (Fig. 1 $a$; Table A1, Category 2). These data indicate that farmed fish are of lower fitness than wild fish in the wild niche (sensu Gross 1998).

\section{Competition in the wild}

Three studies (Webb et al. 1991; Økland et al. 1995; Fleming et al. 2000) directly examined resource competition in the wild (see Table 1, Category 3). The diet of juveniles did not differ significantly between farmed and wild fish (Fleming et al. 2000). However, there were some differences in male mating behaviour (Webb et al. 1991; Fleming et al. 2000), whereby farmed males courted females less frequently than did wild males in three comparisons, but courted more than wild males at the end of the spawning season in one comparison (Webb et al. 1991). Also, the number of males in the spawning area was lower for farmed than wild males in the Økland et al. (1995) study.

\section{Competition in simulated wild or laboratory conditions}

Competition in the laboratory environment was examined by comparing 46 traits in nine different studies, ranging from juvenile diet and predator avoidance to adult spawning behaviour (see Table A1, Category 4). Differences were found in 22 of 46 cases, more than one would expect (Binomial test: $P<0.001$ ) if farmed and wild fish were drawn from the same population (i.e., 2.3 differences out of 46 , assuming $\alpha=0.05$ ). While it is not always clear how trait differences are related to fitness, juvenile aggression (Grant 1990; but see Harwood et al. 2003), male spawning activities (Fleming 1996) and avoidance of predators (Mather 1998) are thought to be positively related to fitness. Farmed 
Table 1. Comparisons used for data analysis summarized by study.

\begin{tabular}{|c|c|c|c|}
\hline Study & No. of comparisons & No. of significant comparisons & Farmed $<$ Wild \\
\hline \multicolumn{4}{|l|}{ 2. Fitness-related traits } \\
\hline Fleming et al. 1996 & 4 & 4 & 4 \\
\hline Fleming et al. 2000 & 5 & 5 & 5 \\
\hline Garant et al. 2003 & 1 & 1 & 0 \\
\hline McGinnity et al. 1997 & 2 & 1 & 1 \\
\hline McGinnity et al. 2003 & 16 & 13 & 10 \\
\hline Thorstad et al. 1998 & 1 & 1 & 0 \\
\hline Weir et al. 2004 & 2 & 2 & 2 \\
\hline Weir et al. 2005 & 2 & 1 & 0 \\
\hline Total & 33 & 28 & 22 \\
\hline \multicolumn{4}{|c|}{ 3. Resource competition in the wild } \\
\hline Fleming et al. 2000 & 4 & 2 & 2 \\
\hline Økland et al. 1995 & 2 & 1 & 1 \\
\hline Webb et al. 1991 & 2 & 2 & 1 \\
\hline Total & 8 & 5 & 4 \\
\hline \multicolumn{4}{|c|}{ 4. Resource competition in the laboratory } \\
\hline Einum and Fleming 1997 & 8 & 5 & 2 \\
\hline Fleming et al. 1996 & 4 & 3 & 3 \\
\hline Fleming and Einum 1997 & 5 & 3 & 1 \\
\hline Garant et al. 2003 & 2 & 2 & 0 \\
\hline Johnsson et al. 2001 & 16 & 3 & 2 \\
\hline Handeland et al. 2003 & 1 & 0 & 0 \\
\hline Weir et al. 2004 & 3 & 3 & 1 \\
\hline Weir et al. 2005 & 4 & 0 & 0 \\
\hline Volpe et al. 2001 & 3 & 3 & 1 \\
\hline Total & 46 & 22 & 10 \\
\hline \multicolumn{4}{|l|}{ 5. Phenotypic traits } \\
\hline Einum and Fleming 1997 & 4 & 3 & 0 \\
\hline Fleming et al. 1996 & 8 & 8 & 4 \\
\hline Fleming et al. 2000 & 28 & 15 & 8 \\
\hline Fleming et al. 2002 & 1 & 1 & 0 \\
\hline Fleming and Einum 1997 & 7 & 5 & 2 \\
\hline Handeland et al. 2003 & 2 & 2 & 1 \\
\hline Heggberget et al. $1993 b$ & 4 & 4 & 1 \\
\hline Lura et al. 1993 & 7 & 2 & 2 \\
\hline Lura and Sægrov 1993 & 5 & 5 & 5 \\
\hline McGinnity et al. 2003 & 7 & 5 & 3 \\
\hline McGinnity et al. 1997 & 4 & 4 & 1 \\
\hline Økland et al. 1995 & 7 & 4 & 0 \\
\hline Thodesen et al. 1999 & 1 & 1 & 0 \\
\hline Thorstad et al. 1998 & 3 & 2 & 0 \\
\hline Webb et al. 1991 & 3 & 3 & 2 \\
\hline Total & 91 & 64 & 29 \\
\hline
\end{tabular}

fish exhibited higher levels of juvenile aggression ( 6 of 8 significant comparisons; total comparisons, $n=10$ ), lower levels of male courtship (4 of 6 significant comparisons; total comparisons, $n=6$ ), and lower levels of predator avoidance (5 of 6 significant comparisons; total comparisons, $n=20$ ) than wild fish, but none of these trends was significant (Sign test: $P>0.10$; Table 1; Fig. $1 b$ ). In summary, competition experiments in the laboratory strongly suggest differences between farmed and 
Fig. 1. Proportion of observations for which farmed fish were more (white bars), equally (grey bars) or less (black bars) successful than wild fish for $(a)$ fitness-related traits (based on seven studies); $(b)$ for behavioural traits (based on six studies); and (c) for phenotypic traits (based on 11 studies). The black bar overlapping 0.5 indicates that farmed fish tend to be less successful than wild fish for a particular comparison.
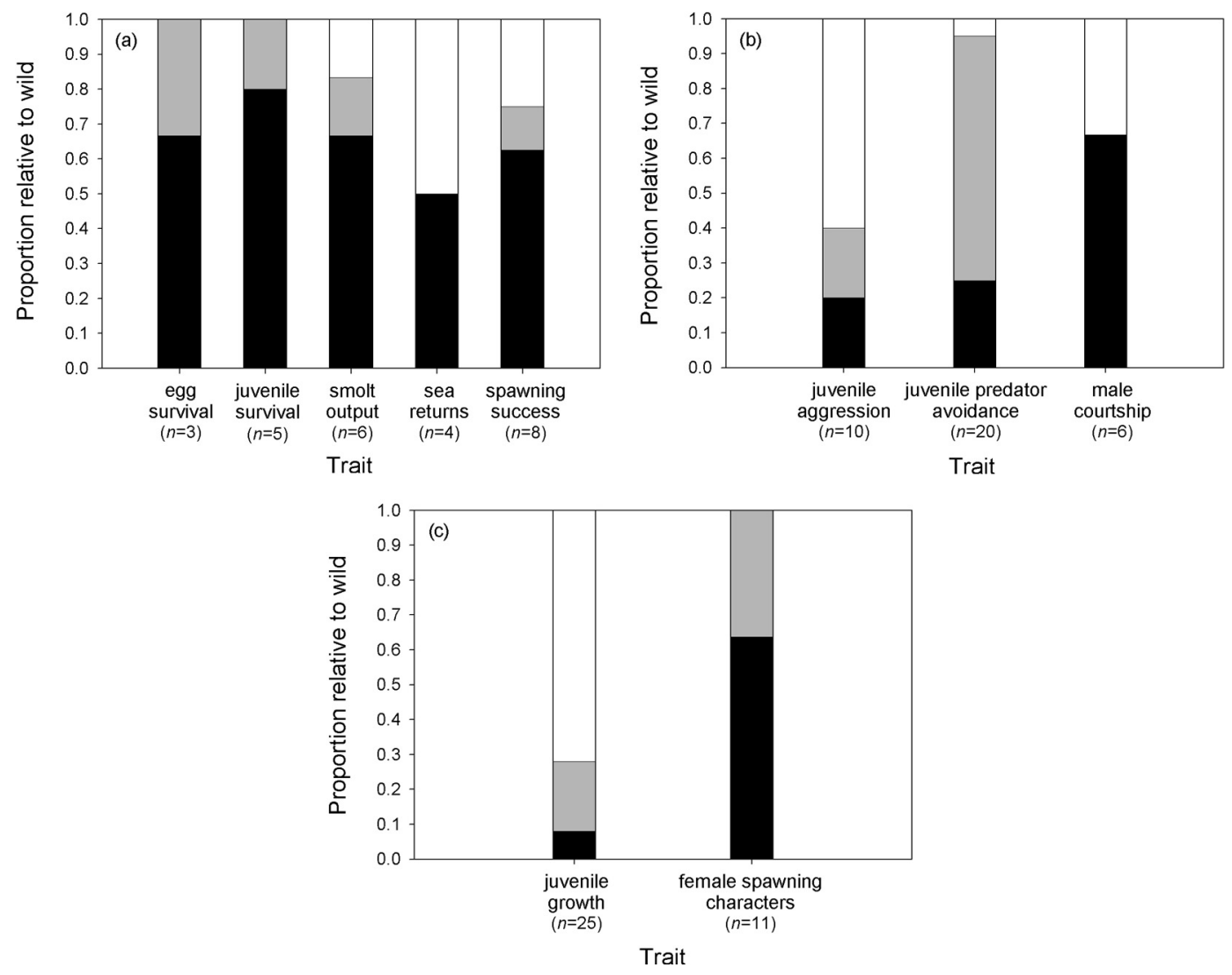

wild salmon, but do not provide consistent evidence regarding whether farmed fish are competitively superior or inferior to wild fish.

\section{Phenotypic and genetic differences}

Fifteen studies compared the phenotype of farmed and wild fish (Table 1, Category 5). Of the 91 comparisons within these studies, 64 differed significantly between fish of farmed and wild origin, many more than expected by chance alone (Binomial test: $P<0.01$ ). There was no significant trend in the direction of the differences for phenotypic traits (Sign test: $P=0.43$ ), but the degree to which direction implies fitness differences is somewhat ambiguous. Some trends were apparent when we compared traits that would seem to be positively related to fitness: juvenile growth rate (Hutchings and Jones 1998) and female spawning behaviour (Fleming 1998). Juvenile growth rate, or related traits (i.e., lower smolt age, larger smolt size), was higher in farmed than in wild fish in 18 of 20 significant comparisons (total comparisons: $n=25$; Sign test: $P<0.001$; Fig. $1 c$ ). However, farmed fish had lower values for traits related to female reproductive success ( 7 of 7 significant comparisons; total comparisons: $n=11$; Sign test: $P=0.016$ ), such as number of nests, eggs per nest, number of spawnings, and amount of female digging. In summary, it seems clear that farmed and wild fish differ in phenotype. Furthermore, 
the data suggest that farmed fish may be superior in traits related to juvenile growth, but inferior in traits related to female reproductive success.

Analyses of molecular genetic differences between farmed and wild fish have been carried out using allozymes, mitochondrial DNA (mtDNA), minisatellites and microsatellites (Table 2). With the exception of Wilson et al. (1995), nine of 10 studies indicated genetic differences between farmed and wild fish at some level (Binomial test: $P=0.05$ ). Differences among the marker types were not evident, but all four markers provided differences that exceeded the expected $5 \%$ difference due to chance alone. Analyses were of two types: allele frequency and diversity (Table $2 a$ ) and genetic divergence from wild populations (Table $2 b$ ). Genetic diversity was lower in farmed than wild fish in 7 of 9 significant comparisons (Sign test: $P=0.18$ ). Allele diversity was significantly higher among farmed fish in only one case (Youngson et al. 1993). Of the six measures of divergence from wild populations using different markers (3 allozymes, 1 microsatellite, and 2 minisatellite markers), all indicated significant genetic differences. In summary, our results provided strong evidence of genetic differences between farmed and wild fish and suggested that farmed fish have lower genetic diversity than wild fish.

\section{Comparisons among studies}

Of the 20 published studies addressing the issue of behavioural interactions and differences in life history traits between farmed and wild salmonids (Table 1), all reported at least one significant difference between farmed and wild fish. Of these, 18 reported differences in most of the traits that were compared, whereas the remaining two studies (Lura et al. 1993; Johnsson et al. 2001) found few or no differences in the traits examined. The studies were of three types: release experiments, hatchery or controlled experiments, and observational studies following identification of farmed individuals in the wild. Of the three studies that found no overall differences, two were hatchery experiments (Johnsson et al. 2001), and the other was observational (Lura et al. 1993).

\section{Comparisons among life stages}

Differences in phenotype between farmed and wild fish were evident at three different stages in the life cycle (Table 1). The proportion of phenotypic traits that differed significantly between farmed and wild fish was independent of life stage (juvenile freshwater: 60\%; marine: 64\%; adult freshwater: 76\%; Goodness-of-fit test: $\left.G_{2}=2.04, P>0.10\right)$. All three life stages had significantly more differences than would be expected by chance alone (Binomial tests: $P$ values $<0.001$ ).

\section{Comparisons among phenotypic categories}

Overall, 121 life history traits, 27 adult behavioural traits, and 32 juvenile behavioural traits (Table 1) were analysed for differences between farmed and wild fish. The percentage of significant differences was highest for adult behavioural traits (75\%), followed by life history traits $(67 \%)$ and was lowest for juvenile behavioural traits (43\%) (Goodness-of-fit test: $G_{2}=9.47, P<0.01$ ). All three categories had significantly more differences than would be expected by chance (Binomial tests: $P$ values $<0.001$ ).

\section{Disease transfer}

Despite many speculative reports regarding disease transfer between farmed and wild organisms, few studies show direct evidence of disease transfer (for a review, see Windsor and Hutchinson 1990; McVicar 1997). This is most likely due to the difficulty in determining where outbreaks occur, and the exact origin of particular pathogens (Anderson 1987, cited in Windsor and Hutchinson 1990; Bakke and Harris 1998). However, Jacobsen and Gaard (1997) found that sea lice abundance and density were higher on escaped farmed than on wild Atlantic salmon, though not in all age classes. Similarly, sea lice infestation on juvenile pink (Oncorhynchus gorbuscha) and chum (Oncorhynchus keta) salmon was markedly higher on individuals sampled close to sea cages (Morton et al. 2004; Krkošek et al. 2005), 


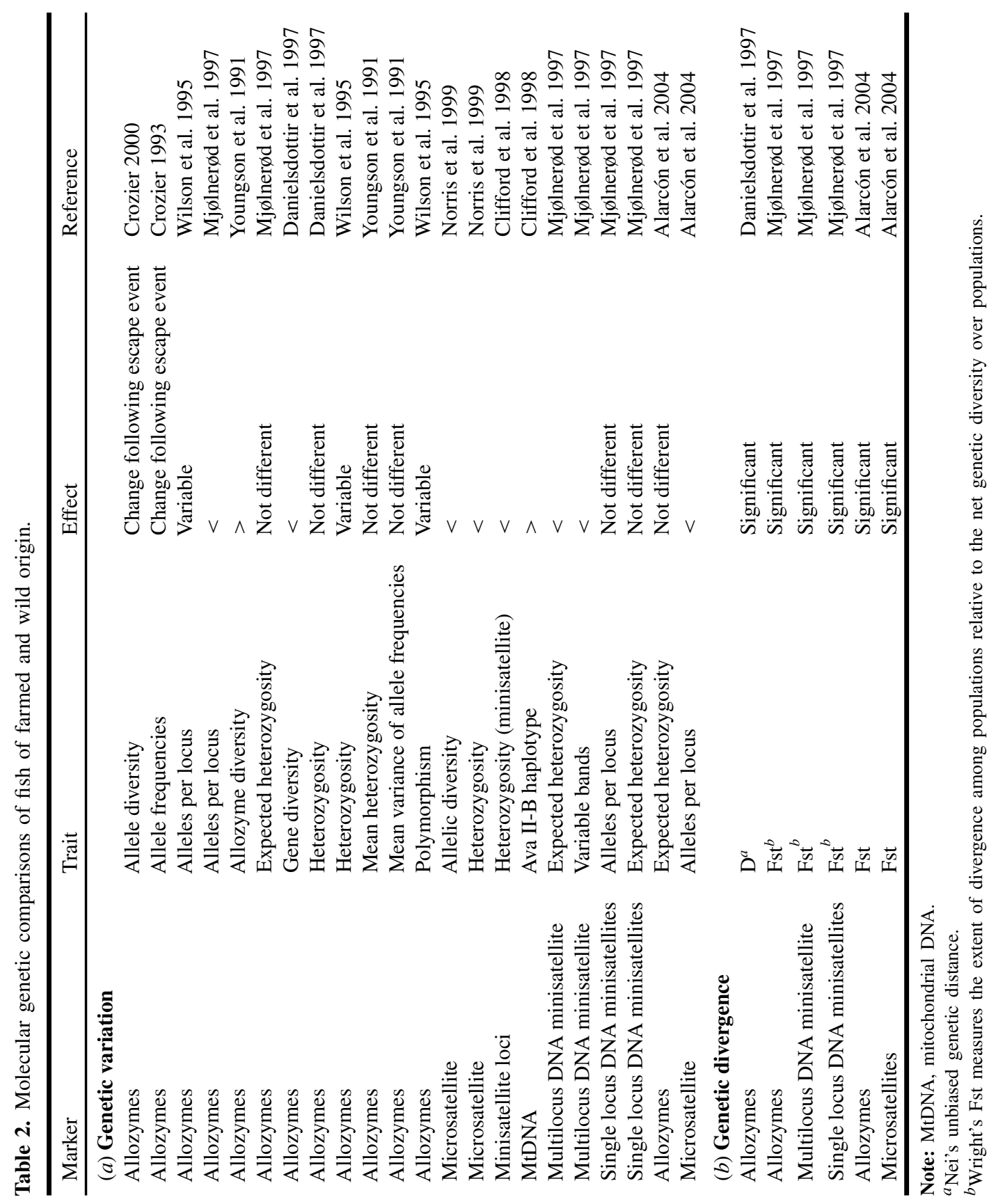


providing compelling evidence that salmon farms can amplify these infestations. Furthermore, Colorni et al. (2002) determined that Streptococcus iniae found on wild lined piggy (Pomadasys stridens) and lizard fish (Synodus variegatus) were the same strain as those found on farmed fish. Similarly, strains of Myobacterium marinum found on rabbitfish (Siganus rivulatus) were the same strain as those found on farmed sea bass (Dicentrarchus labrax) in aquaculture, where the disease was first documented in the Red Sea (Diamant et al. 2000).

\section{Ecosystem effects}

Aquaculture activities have the potential to affect organisms at various levels of taxonomic and community organization. Evidence for changes in bacterial communities (La Rosa et al. 2001; Vezzulli et al. 2002), fish assemblages (Dempster et al. 2002; Machias et al. 2005), bird assemblages (Caldow et al. 2003), and various benthic communities (Brown et al. 1987; Ritz et al. 1989; Weston 1990; Ye et al. 1991; Henderson and Ross 1995; Simenstad and Fresh 1995; Tsutsumi 1995; Mazzola et al. 1999; Stenton-Dozey et al. 1999; Karakassis et al. 2000; Kraufvelin et al. 2001; Molina Domínguez et al. 2001; Pohle et al. 2001; Smith et al. 2001; Mirto et al. 2002; Brooks et al. 2003; Guo and Li 2003; Stephens and Farris 2004) have been investigated for a range of aquaculture species. The general outcome of these studies indicates that any effects of aquaculture activity on the surrounding ecosystem normally occur close to aquaculture sites (i.e., within $5 \mathrm{~km}$ ), and quickly diminish with increasing distance. In addition, effects on benthic communities may continue to occur even after decreases in organic input from aquaculture facilities cease (e.g., Kraufvelin et al. 2001). Unfortunately, the diversity of study organisms, geographical locations, and analytical approaches preclude any proper quantitative analysis of these effects.

\section{Discussion}

Our principal objective was to use the published literature to identify the extent to which farm escapees may ultimately affect the demography of wild populations. Surprisingly, we found no studies directly addressing this issue. Perhaps the best indirect evidence of potential demographic effects comes from rivers where farmed fish outnumber wild individuals (Gausen and Moen 1991; Sægrov et al. 1997; Crozier 2000). Similarly, there are few empirical investigations of fitness differences or competition between farmed and wild fish in natural environments. Given the paucity of data on direct interactions in the wild, we must rely instead on studies of competition in the laboratory, and the many studies of the differences between farmed and wild fish in phenotype and genotype. Our analyses clearly demonstrated that there are many differences between fish of farmed and wild origin, which occur at all life stages for both behavioural and life-history traits.

\section{Genetic and phenotypic differences between farmed and wild fish}

Farmed or hybrid fish generally have lower survival at all life stages, and lower reproductive success than wild fish in the river environment. Offspring survival during early juvenile stages may be influenced by maternal effects on size at hatching due to the smaller egg size of farmed fish (Einum and Fleming 2000). The establishment of farmed populations in rivers may be further affected by the lower spawning success of farmed fish, as suggested by experiments in the wild and under semi-natural conditions (Fleming et al. 1996, 2000; Weir et al. 2004).

While sparse evidence suggests that offspring survival and adult reproductive success is generally lower among farmed than wild fish, resource competition in the wild provides good evidence for the potential impact of farmed fish on wild populations. The limited research on competition in the natural environment suggests that farmed and wild fish compete for the same food resources (Fleming et al. 2000) and spawning opportunities (Webb et al. 1991; Økland et al. 1995; Fleming et al. 2000) thus 
having a potential impact on wild individuals by possibly decreasing available resources and favourable habitats, regardless of the outcome of competitive interactions.

Competitive interactions between farmed and wild fish in the laboratory environment identify further potential differences between farmed and wild fish. Because of small sample sizes, no significant differences between fish of farmed and wild origin were evident. However, the trends suggest that farmed and hybrid juveniles tended to be more aggressive than wild fish, and may outcompete wild fish via interference but consequently may be more susceptible to predation. Conversely, farmed males tended to be less aggressive and courted females less often when in direct competition with wild males (Fleming et al. 1996, 2000). Whether these differences also occur in the wild is not known.

Differences between farmed and wild fish were observed in phenotypic and molecular genetic studies, reflecting the effect that the aquaculture environment and intentional selection can have on organisms. However, no striking trends were apparent, with the exception of juvenile growth rate and traits related to female reproductive success. As expected, there was an overall tendency for farmed and hybrid juveniles to be larger than their wild counterparts, but female reproductive fitness tended to be lower in farmed than in wild fish.

Molecular genetic analyses revealed consistent differences between farmed and wild populations. Differentiation within and among wild Atlantic salmon populations has been documented using allozymes (e.g., Verspoor and Jordan 1989; Verspoor and McCarthy 1997) and microsatellites (McConnell et al. 1995). In many instances, farmed stocks are derived from different rivers and (or) locations with respect to the local wild populations, and some differentiation is to be expected. However, divergence among populations of wild Atlantic salmon is strong (King et al. 2001; Wennevik et al. 2004), and thus differences between farmed and wild populations are to be expected. By contrast, low levels of genetic diversity in farmed stocks reflect changes due to population bottlenecks that occur when broodstock are collected, as well as genetic change following artificial selection. Changes in allele frequencies due to artificial selection have been documented (e.g., Youngson et al. 1991) and may be a concern if differences are created between farmed populations and their wild progenitors (Gross 1998). Given that some local adaptation has been recognized among salmonids (e.g., Taylor 1991), invasion of farmed fish with different genetic makeup may interrupt or alter specialized gene complexes. Genetic change in a wild population following an escape event has been noted (Crozier 1993, 2000), but it is unclear how differences at the molecular genetic level are likely to affect population demographics.

\section{Disease transfer}

Transfer of disease between farmed and wild stocks is poorly understood, partly because the incidence, prevalence, and origin of diseases are difficult to measure in wild populations (McVicar 1997; Bakke and Harris 1998). One of the most widely studied disease outbreaks, the spread of Gyrodactylus in European waters, was thought to be generated by stocking hatchery parr in Norwegian rivers (Malmberg 1989, cited in Johnsen and Jensen 1991). Similarly, outbreaks of furunculosis, caused by the bacterial pathogen Aeromonas salmonicida, were hypothesized to have been caused by escapees from farm facilities (Johnsen and Jensen 1994). Disease transfer may initially occur mainly from wild to farmed fish, and then spread rapidly within farmed fish due to their holding conditions (Håstein and Lindstad 1991). The strains of pathogens found on farmed and wild fish are often identical (Colorni et al. 2002; Diamant et al. 2000), however the direction of transfer between stocks remains speculative. The best evidence of pathogen transfer from farmed to wild fish comes from a recent study of sea lice outbreaks in native Pacific salmon (Krkošek et al. 2005).

\section{Ecosystem effects}

A broad range of studies report changes in community structure only in the immediate vicinity of the aquaculture facilities (e.g., Brown et al. 1987; Weston 1990; Tsutsumi 1995). These studies undoubtedly underestimate the real "ecological footprint" (Rees 1992) of intensive aquaculture. Perhaps 
the greatest ecosystem effect will be related to the exploitation of wild fish populations to produce fish food for intensive aquaculture. The ecological footprint of this "indirect" effect of aquaculture is typically estimated to be greater than the more direct and local effect of waste assimilation near fish farms (Folke et al. 1998; Naylor et al. 2000).

\section{Potential effects of farmed escapees on wild populations}

Our analysis suggests that the potential impacts of farmed fish are varied and context-dependent. The demographic consequences resulting from farmed fish entering natural environments depend upon a number of factors, such as the population size of wild fish, the number, life stage, and frequency with which farmed individuals enter the natural environment, the origin and rearing history of farmed fish, and the breeding success within and between groups of farmed and wild adults (Hutchings 1991). Our results indicate that farmed fish differ from wild fish for a wide variety of traits, though the direction of these differences was generally inconsistent. However, the most important traits from a population persistence and growth rate perspective - survival and reproductive success - tended to be lower among individuals of farmed origin. Thus, if small-scale escapes occur whereby farmed fish enter a river system where local population sizes are large, the impact may be slight. Conversely, populations near carrying capacity might be more threatened, even in the absence of interbreeding, due to increased resource competition and predation hazard if many farmed fish enter the river environment. The biggest threat may occur when large numbers of farmed fish invade small wild populations. Under these circumstances, the lower fitness of farmed fish and low interbreeding between forms will be offset by the sheer numbers of invaders.

Interestingly, the scarcity of evidence regarding farmed and wild fish spawning interactions is contrasted dramatically by the extensive evidence examining differences between hatchery and wild fish. In a recent review of the literature concerning the latter, Fleming and Petersson (2001) concluded that hatchery fish "generally fail to attain self-sustainability and (or) contribute significantly to populations".

Data in the published literature clearly indicate that farmed fish tend to be less fit than wild conspecifics. However, the lack of information addressing demographic consequences of the escape of farmed fish is a major gap in our understanding of the environmental impact of the aquaculture industry. While several excellent studies have attempted to assess success over generations (e.g., Fleming et al. 2000; McGinnity et al. 2003), data on population level changes following escapes is necessary to resolve whether farmed fish have the ability to cause major damage to wild populations. Such data would prove invaluable to the management of wild populations and to the promotion of sustainable aquaculture practices. Furthermore, available studies also indicate that there is substantial variability in the performance of farmed fish relative to wild, and as such the effects of aquaculture escapees on wild stocks is dependent upon to context in which escapes occur.

\section{Recommendations}

Given the paucity of data regarding the population consequences of escaped farmed fish on wild populations, we recommend four types of studies.

(1) Detailed case studies of the dynamics of invasion or farmed fish into wild populations are needed. Existing data should be published.

(2) Manipulative experiments in which known numbers of farmed fish are introduced into wild populations are urgently required. McGinnity et al. (2003) study provides a good model for the type of study that is required

(3) The population consequences of any new escapes of farmed fish need to be thoroughly monitored in an opportunistic way.

(4) Hutching's (1991) context-dependent model should be tested as data become available. 


\section{Conclusions}

(1) There is a striking deficiency of data regarding the effects of escaped farmed fish on wild fish populations. Although the escape of farmed fish has been implicated in the endangerment of some wild populations (e.g., COSEWIC: Inner Bay of Fundy Atlantic salmon), conclusive evidence is lacking.

(2) While data are not extensive, available evidence suggests that farmed fish are of lower fitness than wild fish in the natural environment.

(3) The few available data suggest that escaped farmed fish will compete with wild fish.

(4) Many studies show marked phenotypic and genetic differences between farmed and wild salmon, likely due to artificial selection in the aquaculture environment. Escaped farmed salmon should clearly be treated as exotic populations and (or) species.

(5) Evidence of disease transfer between farmed and wild salmon is largely correlational and deserves further experimental study.

(6) Localized effects of intensive aquaculture have been well studied, albeit in a diverse manner. Better estimates of the direct and indirect effects of aquaculture on both a local and regional spatial scale are needed.

(7) Given the fragmentary data that are available regarding direct effects of farmed fish on wild populations and ecosystems and the existing information regarding fitness, phenotypic, and genotypic differences between farmed and wild fish, a careful application of the precautionary principle is desirable.

\section{Acknowledgements}

We thank Ian Fleming for input during the earlier stages of this work and Jeff Hutchings and two referees for commenting on the manuscript. This work was supported by funds from AquaNet N.C.E. to J.W.A. Grant.

\section{References}

Alarcón, J.A., Magoulas, A., Georgakopoulos, T., Zouros, E., and Alvarez, M.C. 2004. Genetic comparisons of wild and cultivated sea bream (Sparus aurata). Aquaculture, 230: 65-80.

Anderson, J.M. 1987. Effects of aquaculture on salmon management. In Proceedings of the Symposium on Present and Future Atlantic Salmon Management, Portland, Maine, 27-29 October 1987. Edited by R.H. Stroud. Atlantic Salmon Federation and National Coalition for Marine Conservation, Savannah, Ga.

Bakke, T.A., and Harris, P.D. 1998. Diseases and parasites in wild Atlantic salmon (Salmo salar) populations. Can. J. Fish. Aquat. Sci. 55(Suppl. 1): 247-266.

Begon, M., Harper, J.L., and Townsend, C.R. 1996. Ecology. 3rd ed. Blackwell Science, Oxford, UK.

Brooks, K.M., Stierns, A.R., Mahnken, C.V.W., and Blackburn, D.B. 2003. Chemical and biological remediation of the benthos near Atlantic salmon farms. Aquaculture, 219: 355-377.

Brown, J.R., Gowen, R.J., and McLusky, D.S. 1987. The effect of salmon farming on the benthos of a Scottish sea loch. J. Exp. Mar. Biol. Ecol. 109: 39-51.

Butler, J.R.A., Cunningham, P.D., and Starr, K. 2005. The prevalence of escaped farmed salmon, Salmo salar, in the River Ewe, western Scotland, with notes on their ages, weights and spawning distribution. Fish. Manag. Ecol. 12: 149-159.

Caldow, R.W.G., Beadman, H.A., McGrorty, S., Kaiser, M.J., Goss-Custard, J.D., Mould, K., and Wilson, A. 2003. Effects of intertidal mussel cultivation on bird assemblages. Mar. Ecol. Prog. Ser. 259: 173-183.

Carr, J.W., Anderson, J.M., Whoriskey, F.G., and Dilworth, T. 1997. The occurrence and spawning of cultured Atlantic salmon (Salmo salar) in a Canadian river. ICES J. Mar. Sci. 54: 1064-1073. 
Clifford, S.L., McGinnity, P., and Ferguson, A. 1998. Genetic changes in an Atlantic salmon population resulting from escaped juvenile farm salmon. J. Fish Biol. 52: 118-127.

Colorni, A., Diamant, A., Eldar, A., Kvitt, H., and Zlotkin, A. 2002. Streptococcus iniae infections in Red Sea cage-cultured and wild fishes. Dis. Aquat. Org. 49: 165-170.

Crozier, W.W. 1993. Evidence of genetic interaction between escaped farmed salmon and wild Atlantic salmon (Salmo salar L.) in a Northern Irish river. Aquaculture, 113: 19-29.

Crozier, W.W. 1998. Incidence of escaped farmed salmon, Salmo salar L., in commercial salmon catches and fresh water in Northern Ireland. Fish. Manag. Ecol. 5: 23-29.

Crozier, W.W. 2000. Escaped farmed salmon, Salmo salar L., in the Glenarm River, Northern Ireland: genetic status of the wild population 7 years on. Fish. Manag. Ecol. 7: 437-446.

Danielsdottir, A.K., Marteinsdottir, G., Arnason, F., and Gudjonsson, S. 1997. Genetic structure of wild and reared Atlantic salmon (Salmo salar L.) populations in Iceland. ICES J. Mar. Sci. 54: 986-997.

Dempster, T., Sanchez-Jerez, P., Bayle-Sempere, J.T., Giménez-Casalduero, F., and Valle, C. 2002. Attraction of wild fish to sea-cage fish farms in the south-western Mediterranean Sea: spatial and short-term temporal variability. Mar. Ecol. Prog. Ser. 242: 237-252.

Diamant, A., Banet, A., Ucko, M., Colorni, A., Knibb, W., and Kvitt, H. 2000. Mycobacteriosis in wild rabbitfish Siganus rivulatus associated with cage farming in the Gulf of Eliat, Red Sea. Dis. Aquat. Org. 39: 211-219.

Einum, S., and Fleming, I.A. 1997. Genetic divergence and interactions in the wild among native, farmed, and hybrid Atlantic salmon. J. Fish Biol. 50: 634-651.

Einum, S., and Fleming, I.A. 2000. Selection against late emergence and small offspring in Atlantic salmon (Salmo salar). Evolution, 52: 628-639.

Einum, S., and Fleming, I.A. 2001. Implications of stocking: ecological interactions between wild and released salmonids. Nord. J. Freshw. Res. 75: 56-70.

Fleming, I.A. 1996. Reproductive strategies of Atlantic salmon: ecology and evolution. Rev. Fish Biol. Fish. 6: $379-416$.

Fleming, I.A. 1998. Pattern and variability in the breeding system of Atlantic salmon (Salmo salar), with comparisons to other salmonids. Can. J. Fish. Aquat. Sci. 55(Suppl. 1): 59-76.

Fleming, I.A., and Einum, S. 1997. Experimental tests of genetic divergence of farmed from wild Atlantic salmon due to domestication. ICES J. Mar. Sci. 54: 1051-1063.

Fleming, I.A., and Petersson, E. 2001. The ability of released, hatchery salmonids to breed and contribute to the natural productivity of wild populations. Nord. J. Freshw. Res. 75: 71-98.

Fleming, I.A., Jonsson, B., Gross, M.R., and Lamberg, A. 1996. An experimental study of the reproductive behaviour and success of farmed and wild Atlantic salmon (Salmo salar). J. Appl. Ecol. 33: 893-905.

Fleming, I.A., Hindar, K., Mjølnerød, I.B., Jonsson, B., Balstad, T., and Lamberg, A. 2000. Lifetime success and interactions of farm salmon invading a native population. Proc. R. Soc. Lond. B, Biol. Sci. 267: $1517-1523$.

Fleming, I.A., Agustsson, T., Finstad, B., Johnsson, J.I., and Björnsson, B.Th. 2002. Effects of domestication on growth physiology and endocrinology of Atlantic salmon (Salmo salar). Can. J. Fish. Aquat. Sci. 59: $1323-1330$.

Folke, C., Kautsky, N., Berg, H., Jansson, A., and Troell, M. 1998. The ecological footprint concept for sustainable seafood production: a review. Ecol. Appl. 8: S63-S71.

Garant, D., Fleming, I.A., Einum, S., and Bernatchez, L. 2003. Alternative male life-history tactics as potential vehicles for speeding introgression of farm salmon traits into wild populations. Ecol. Lett. 6: 541-549.

Gausen, D., and Moen, V. 1991. Large-scale escapes of farmed Atlantic salmon (Salmo salar) into Norwegian rivers threaten natural populations. Can. J. Fish. Aquat. Sci. 48: 426-428.

Gjedrem, T., Salte, R., and Gjøen, H.M. 1991. Genetic variation in susceptibility of Atlantic salmon to furunculosis. Aquaculture, 97: 1-6.

Gjerde, B. 1984. Response to individual selection for age at sexual maturity in Atlantic salmon. Aquaculture, 38: $229-240$.

Grant, J.W.A. 1990. Aggressiveness and the foraging behaviour of young-of-the-year brook charr (Salvelinus fontinalis). Can. J. Fish. Aquat. Sci. 47: 915-920.

Gross, M.R. 1998. One species with two biologies: Atlantic salmon (Salmo salar) in the wild and in 
aquaculture. Can. J. Fish. Aquat. Sci. 55(Suppl. 1): 131-144.

Gudjonsson, S. 1991. Occurrence of reared salmon in natural salmon rivers in Iceland. Aquaculture, 98: 133-142.

Guo, L., and Li, Z. 2003. Effects of nitrogen and phosphorus from fish cage-culture on the communities of a shallow lake in middle Yangtze River basin of China. Aquaculture, 226: 201-212.

Handeland, S.O., Björnsson, B.Th., Arnesen, A.M., and Stefansson, S.O. 2003. Seawater adaptation and growth of post-smolt Atlantic salmon ( Salmo salar) of wild and farmed strains. Aquaculture, 220: 367-384.

Hansen, L.P., and Jacobsen, J.A. 2003. Origin and migration of wild and escaped farmed Atlantic salmon, Salmo salar L., in oceanic areas north of the Faroe Islands. ICES J. Mar. Sci. 60: 110-119.

Hansen, L.P., Reddin, D.G., and Lund, R.A. 1997. The incidence of reared Atlantic salmon (Salmo salar L.) of fish farm origin at West Greenland. ICES J. Mar. Sci. 54: 152-155.

Hansen, L.P., Jacobsen, J.A., and Lund, R.A. 1999. The incidence of escaped farmed Atlantic salmon, Salmo salar L., in the Faroese fishery and estimates of catches of wild salmon. ICES J. Mar. Sci. 56: 200-206.

Harwood, A.J., Griffiths, S.W., Metcalfe, N.B., and Armstrong, J.D. 2003. The relative influence of prior residency and dominance on the early feeding behaviour of juvenile Atlantic salmon. Anim. Behav. 65: 1141-1149.

Håstein, T., and Lindstad, T. 1991. Diseases in wild and cultured salmon: possible interaction. Aquaculture, 98: $277-288$.

Heggberget, T.G., Johnsen, B.O., Jonsson, B., Hansen, L.P., Hvidsten, N.A., and Jensen, A.J. $1993 a$. Interactions between wild and cultured Atlantic salmon: a review of the Norwegian experience. Fish. Res. 18: $123-146$.

Heggberget, T.G., Økland, F., and Ugedal, O. 1993b. Distribution and migratory behaviour of adult wild and farmed Atlantic salmon (Salmo salar) during return migration. Aquaculture, 118: 73-83.

Henderson, A.R., and Ross, D.J. 1995. Use of macrobenthic infaunal communities in the monitoring and control of the impact of marine cage fish farming. Aquac. Res. 26: 659-678.

Hindar, K., Ryman, N., and Utter, F. 1991. Genetic effects of cultured fish on natural populations. Can. J. Fish. Aquat. Sci. 48: 945-957.

Hites, R.A., Foran, J.A., Carpenter, D.O., Hamilton, M.C., Knuth, B.A., and Schwager, S.J. 2004. Global assessment of organic contaminants in farmed salmon. Science, 303: 226-229.

Hutchings, J.A. 1991. The threat of extinction to native populations experiencing spawning intrusions by cultured Atlantic salmon. Aquaculture, 98: 119-132.

Hutchings, J.A., and Jones, M.E.B. 1998. Life history variation and growth rate thresholds for maturity in Atlantic salmon, Salmo salar. Can. J. Fish. Aquat. Sci. 55(Suppl. 1): 22-47.

Jacobsen, J.A., and Gaard, E. 1997. Open-ocean infestation by salmon lice (Lepeophtherius salmonis): comparison of wild and escaped farmed Atlantic salmon (Salmo salar L.). ICES J. Mar. Sci. 54: 11131119.

Johnsen, B.O., and Jensen, A.J. 1991. The Gyrodactylus story in Norway. Aquaculture, 98: 289-302.

Johnsen, B.O., and Jensen, A.J. 1994. The spread of furunculosis in salmonids in Norwegian rivers. J. Fish Biol. 45: 47-55.

Johnsson, J.I., Höjesjö, J., and Fleming, I.A. 2001. Behavioural and heart rate responses to predation risk in wild and domesticated Atlantic salmon. Can. J. Fish. Aquat. Sci. 58: 788-794.

Jonsson, B. 1997. A review of ecological and behavioural interactions between cultured and wild Atlantic salmon. ICES J. Mar. Sci. 54: 1031-1039.

Karakassis, I., Tsapakis, M., Hatziyanni, E., Papadopoulou, K.-N., and Plaiti, W. 2000. Impact of cage farming of fish on the seabed in three Mediterranean coastal areas. ICES J. Mar. Sci. 57: 1462-1471.

King, T.L., Kalinowski, S.T., Schill, W.B., Spidle, A.P., and Lubinski, B.A. 2001. Population structure of Atlantic salmon (Salmo salar L.): a range-wide perspective from microsatellite DNA variation. Mol. Ecol. 10: $807-821$.

Kraufvelin, P., Sinisalo, B., Leppakoski, E., Mattila, J., and Bonsdorff, E. 2001. Changes in zoobenthic community structure after pollution abatement from fish farms in the Archipelago Sea (N. Baltic Sea). Mar. Environ. Res. 51: 229-245.

Krkošek, M., Lewis, M.A., and Volpe, J.P. 2005. Transmission dynamics of parasitic sea lice from farm to wild salmon. Proc. R. Soc. Lond. B, Biol. Sci. 272: 689-696. 
La Rosa, T., Mirto, S., Marino, A., Alonzo, V., Maugeri, T.L., and Mazzola, A. 2001. Heterotrophic bacteria community and pollution indicators of mussel-farm impact in the Gulf of Gaeta (Tyrrhenian Sea). Mar. Environ. Res. 52: 301-321.

Lund, R.A., Økland, F., and Hansen, L.P. 1991. Farmed Atlantic salmon (Salmo salar) in fisheries and rivers in Norway. Aquaculture, 98: 143-150.

Lura, H., and Sægrov, H. 1991. Documentation of successful spawning of escaped farmed female Atlantic salmon, Salmo salar, in Norwegain rivers. Aquaculture, 98: 151-159.

Lura, H., and Sægrov, H. 1993. Timing of spawning in cultured and wild Atlantic salmon (Salmo salar) and brown trout (Salmo trutta) in the River Vosso, Norway. Ecol. Freshw. Fish. 2: 167-172.

Lura, H., Barlaup, B.T., and Sægrov, H. 1993. Spawning behaviour of a farmed escaped female Atlantic salmon (Salmo salar). J. Fish Biol. 42: 311-313.

Machias, A., Karakassis, I., Giannoulaki, M., Papadopoulou, K.N., Smith, C.J., and Somarakis, S. 2005. Response of demersal fish communities to the presence of fish farms. Mar. Ecol. Prog. Ser. 288: 241-450.

Malmberg, G. 1989. Salmonid transports: culturing and Gyrodactylus infections in Scandinavia. In Parasites of Freshwater Fishes of North-West Europe. International Symposium Soviet-Finnish Cooperation, September 1988. Edited by O. Bauer. Institute of Biology, USSR Academy of Science, Karelian Branch, Petrozavodsk, USSR. pp. 88-104.

Mather, M.E. 1998. The role of context-specific predation in understanding patterns exhibited by anadromous salmon. Can. J. Fish. Aquat. Sci. 55(Suppl. 1): 232-246.

Mather, M.E., Parrish, D.L., Folt, C.L., and DeGraaf, R.M. 1998. Integrating across scales: effectively applying science for the successful conservation of Atlantic salmon (Salmo salar). Can. J. Fish. Aquat. Sci. 55(Suppl. 1): 1-8.

Mazzola, A., Mirto, S., and Danovaro, R. 1999. Initial fish-farm impact on meiofaunal assemblages in coastal sediments of the western Mediterranean. Mar. Pollut. Bull. 38: 1126-1133.

McConnell, S., O’Reilly, P., Hamilton, L., Wright, J.M., and Bentzen, P. 1995. Polymorphic microsatellite loci from Atlantic salmon ( Salmo salar): genetic differentiation of North American and European populations. Can. J. Fish. Aquat. Sci. 52: 1863-1872.

McGinnity, P., Stone, C., Taggart, J.B., Cooke, D., Cotter, D., Hynes, R., McCamley, C., Cross, T., and Ferguson, A. 1997. Genetic impact of escaped farmed Atlantic salmon (Salmo salar L.) on native populations: use of DNA profiling to assess freshwater performance of wild, farmed, and hybrid progeny in a natural river environment. ICES J. Mar. Sci. 54: 998-1008.

McGinnity, P., Prodöhl, P., Ferguson, A., Hynes, R., Maoilédigh, N.Ó., Baker, N., Cotter, D., O’Hea, B., Cooke, D., Rogan, G., Taggart, J., and Cross, T. 2003. Fitness reduction and potential extinction of wild populations of Atlantic salmon Salmo salar as a result of interactions with escaped farm salmon. Proc. R. Soc. Lond. B, Biol. Sci. 270: 2443-2450.

McKinnell, S., and Thomson, A.J. 1997. Recent events concerning Atlantic salmon escapees in the Pacific. ICES J. Mar. Sci. 54: 1221-1225.

McKinnell, S., Black, E.A., Wing, B.L., Guthrie, C.M., III, Koerner, J.F., and Helle, J.H. 1997. Atlantic salmon in the North Pacific. Aquac. Res. 28: 145-157.

McVicar, A.H. 1997. Disease and parasite implications of the coexistence of wild and farmed cultured Atlantic salmon populations. ICES J. Mar. Sci. 54: 1093-1103.

Milner, N.J., and Evans, R. 2003. The incidence of escaped Irish farmed salmon in English and Welsh rivers. Fish. Manag. Ecol. 10: 403-406.

Mirto, S., La Rosa, T., Gambi, C., Danovaro, R., and Mazzola, A. 2002. Nematode community response to fish-farm impact in the western Mediterranean. Environ. Pollut. 116: 203-214.

Mjølnerød, I.B., Refseth, U.H., Karlsen, E., Balstad, T., Jakobsen, K.S., and Hindar, K. 1997. Genetic differences between two wild and one farmed population of Atlantic salmon (Salmo salar) revealed by three classes of genetic markers. Hereditas, 127: 239-248.

Molina Domínguez, L., López Calero, G., Vergara Martín, J.M., and Robaina Robaina, L. 2001. A comparative study of sediments under a marine cage farm at Gran Canaria Island (Spain). Preliminary results. Aquaculture, 192: 225-231.

Morton, A., Routledge, R., Peet, C., and Ladwig, A. 2004. Sea lice (Lepeophtheirus salmonis) infection rates on juvenile pink (Oncorhynchus gorbuscha) and chum (Oncorhynchus keta) salmon in the nearshore marine environment of British Columbia, Canada. Can. J. Fish. Aquat. Sci. 61: 147-157. 
Naylor, R.L., Goldburg, R.J., Primavera, J.H., Kautsky, N., Beveridge, M.C.M., Clay, J., Folke, C., Lubchenco, J., Mooney, H., and Troell, M. 2000. Effect of aquaculture on world fish supplies. Nature (Lond.), 405: 1017-1024.

Naylor, R., Hindar, K., Fleming, I.A., Goldburg, R., Williams, S., Volpe, J., Whoriskey, F., Eagle, J., Kelso, D., and Mangel, M. 2005. Fugitive salmon: assessing the risks of escaped fish from net-pen aquaculture. Bioscience, 55: 427-437.

Norris, A.T., Bradley, D.G., and Cunningham, E.P. 1999. Microsatellite genetic variation between and within farmed and wild Atlantic salmon (Salmo salar) populations. Aquaculture, 180: 247-264.

Økland, F., Heggberget, T.G., and Jonsson, B. 1995. Migratory behaviour of wild and farmed Atlantic salmon (Salmo salar) during spawning. J. Fish Biol. 46: 1-7.

Pohle, G., Frost, B., and Findlay, R. 2001. Assessment of regional benthic impact of salmon mariculture within the Letang Inlet, Bay of Fundy. ICES J. Mar. Sci. 58: 417-426.

Poole, W.R., Webb, J.H., Matthews, M.A., and Youngson, A.F. 2000. Occurrence of canthaxanthin in Atlantic salmon, Salmo salar L., fry in Irish rivers as an indicator of escaped farmed salmon. Fish. Manag. Ecol. 7: 377-385.

Rees, W.E. 1992. Ecological footprints and appropriated carrying capacity: what urban economics leaves out. Environ. Urban. 4: 121-130.

Ritz, D.A., Lewis, M.E., and Shen, M. 1989. Response to organic enrichment of infaunal macrobenthic communities under salmonid seacages. Mar. Biol. 103: 211-214.

Sægrov, H., Hindar, K., Kålås, S., and Lura, H. 1997. Escaped farmed Atlantic salmon replace the original salmon stock in the River Vosso, western Norway. ICES J. Mar. Sci. 54: 1166-1172.

Saunders, R.L. 1991. Potential interaction between cultured and wild Atlantic salmon. Aquaculture, 98: 51-60.

Simenstad, C.A., and Fresh, K.L. 1995. Influence of intertidal aquaculture on benthic communities in Pacific Northwest estuaries. Estuaries, 18: 43-70.

Smith, A.C., Martin, J.L., Ehrman, J.M., and Kaczmarska, I. 2001. Ten-year record of Thalassiosira nordenskioeldii population dynamics: comparison of aquaculture and non-aquaculture sites in the Quoddy region. ICES J. Mar. Sci. 58: 391-397.

Stenton-Dozey, J.M.E., Jackson, L.F., and Busby, A.J. 1999. Impact of mussel culture on macrobenthic community structure in Saldanha Bay, South Africa. Mar. Pollut. Bull. 39: 357-366.

Stephens, W.W., and Farris, J.L. 2004. Instream community assessment of aquaculture effluents. Aquaculture, 231: $149-162$.

Stokesbury, M.J., and Lacroix, G.L. 1997. High incidence of hatchery origin Atlantic salmon in the smolt output of a Canadian River. ICES J. Mar. Sci. 54: 1074-1081.

Stokesbury, M.J., Lacroix, G.L., Price, E.L., Knox, D., and Dadswell, M.J. 2001. Identification by scale analysis of farmed Atlantic salmon juveniles in southwestern New Brunswick rivers. Trans. Am. Fish. Soc. 130: $815-822$.

Taylor, E.B. 1991. A review of local adaptation in Salmonidae, with particular reference to Pacific and Atlantic salmon. Aquaculture, 98: 185-207.

Thodesen, J., Grisdale-Halland, B., Helland, S.J., and Gjerde, B. 1999. Feed intake, growth, and feed utilization of offspring from wild and selected Atlantic salmon (Salmo salar). Aquaculture, 180: 237-246.

Thorpe, J.E. 2004. Life history responses of fishes to culture. J. Fish Biol. 65(Suppl. A): 263-285.

Thorstad, E.B., Heggberget, T.G., and Økland, F. 1998. Migratory behaviour of adult wild and escaped farmed Atlantic salmon, Salmo salar L., before, during and after spawning in a Norwegian river. Aquac. Res. 29: 419-428.

Tsutsumi, H. 1995. Impact of fish net pen culture on the benthic environment of a cove in south Japan. Estuaries, 18: 108-115.

Utter, F., and Epifanio, J. 2002. Marine aquaculture: genetic potentialities and pitfalls. Rev. Fish Biol. Fish. 12: $59-77$.

Verspoor, E. 1997. Genetic diversity among Atlantic salmon (Salmo salar L.) populations. ICES J. Mar. Sci. 54: 965-973.

Verspoor, E., and Jordan, W.C. 1989. Genetic variation at the Me-2 locus in the Atlantic salmon within and between rivers: evidence for its selective maintenance. J. Fish Biol. 35(Suppl. A): 205-213.

Verspoor, E., and McCarthy, E. 1997. Genetic divergence at the NAD+-dependent malic enzyme locus in 
Atlantic salmon from Europe and North America. J. Fish Biol. 50: 155-163.

Vezzulli, L., Chelossi, E., Riccardi, G., and Fabiano, M. 2002. Bacterial community structure and activity in fish farm sediments of the Ligurian sea (Western Mediterranean). Aquac. Int. 10: 123-141.

Volpe, J.P., Taylor, E.B., Rimmer, D.W., and Glickman, B.W. 2000. Evidence of natural reproduction of aquaculture-escaped Atlantic salmon in a coastal British Columbia river. Conserv. Biol. 14: 899-903.

Volpe, J.P., Anholt, B.R., and Glickman, B.W. 2001. Competition among juvenile Atlantic salmon (Salmo salar) and steelhead (Oncorhynchus mykiss): relevance to invasion potential in British Columbia. Can. J. Fish. Aquat. Sci. 58: 197-207.

Webb, J.H., Hay, D.W., Cunningham, P.D., and Youngson, A.F. 1991. The spawning behaviour of escaped farmed and wild adult Atlantic salmon (Salmo salar L.) in a northern Scottish river. Aquaculture, 98: 97-110.

Webb, J.H., Youngson, A.F., Thompson, C.E., Hay, D.W., Donaghy, M.J., and McLaren, I.S. 1993. Spawning of escaped farmed Atlantic salmon, Salmo salar L., in western and northern Scottish rivers: egg deposition by females. Aquac. Fish. Manag. 24: 663-670.

Weir, L.K., Hutchings, J.A., Fleming, I.A., and Einum, S. 2004. Dominance relationships and behavioural correlates of spawning success in farmed and wild male Atlantic salmon, Salmo salar. J. Anim. Ecol. 73: 1069-1079.

Weir, L.K., Hutchings, J.A., Fleming, I.A., and Einum, S. 2005. Spawning behaviour and success of mature male Atlantic salmon (Salmo salar) parr of farmed and wild origin. Can. J. Fish. Aquat. Sci. 62: $1153-1160$.

Wennevik, V., Skaala, Ø., Titov, S.F., Studyonov, I., and Nævdal, G. 2004. Microsatellite variation in populations of Atlantic salmon from North Europe. Environ. Biol. Fishes, 69: 143-152.

Weston, D.P. 1990. Quantitative examination of macrobenthic community changes along an organic enrichment gradient. Mar. Ecol. Prog. Ser. 61: 233-244.

Wilson, I.F., Bourke, E.A., and Cross, T.F. 1995. Genetic variation at traditional and novel allozyme loci, applied to interactions between wild and reared Salmo salar L. (Atlantic salmon). Heredity, 75: 578-588.

Windsor, M.L., and Hutchinson, P. 1990. The potential interactions between salmon aquaculture and the wild stocks - a review. Fish. Res. 10: 163-176.

Ye, L.-X., Ritz, D.A., Fenton, G.E., and Lewis, M.E. 1991. Tracing the influence on sediments of organic waste from a salmonid farm using stable isotope analysis. J. Exp. Mar. Biol. Ecol. 145: 161-174.

Youngson, A.F., and Verspoor, E. 1998. Interactions between wild and introduced Atlantic salmon (Salmo salar). Can. J. Fish. Aquat. Sci. 55(Suppl.1): 153-160.

Youngson, A.F., Martin, S.A.M., Jordan, W.C., and Verspoor, E. 1991. Genetic protein variation in Atlantic salmon in Scotland: comparison of wild and farmed fish. Aquaculture, 98: 231-242.

Youngson, A.F., Webb, J.H., Thompson, C.E., and Knox, D. 1993. Spawning of escaped farmed Atlantic salmon (Salmo salar): hybridization of females with brown trout. Can. J. Fish. Aquat. Sci. 50: 1986-1990.

Youngson, A.F., Dosdat, A., Sargolia, M., and Jordan, W.C. 2001. Genetic interactions between marine finfish species in European aquaculture and wild conspecifics. J. Appl. Ichthyol. 17: 153-162. 


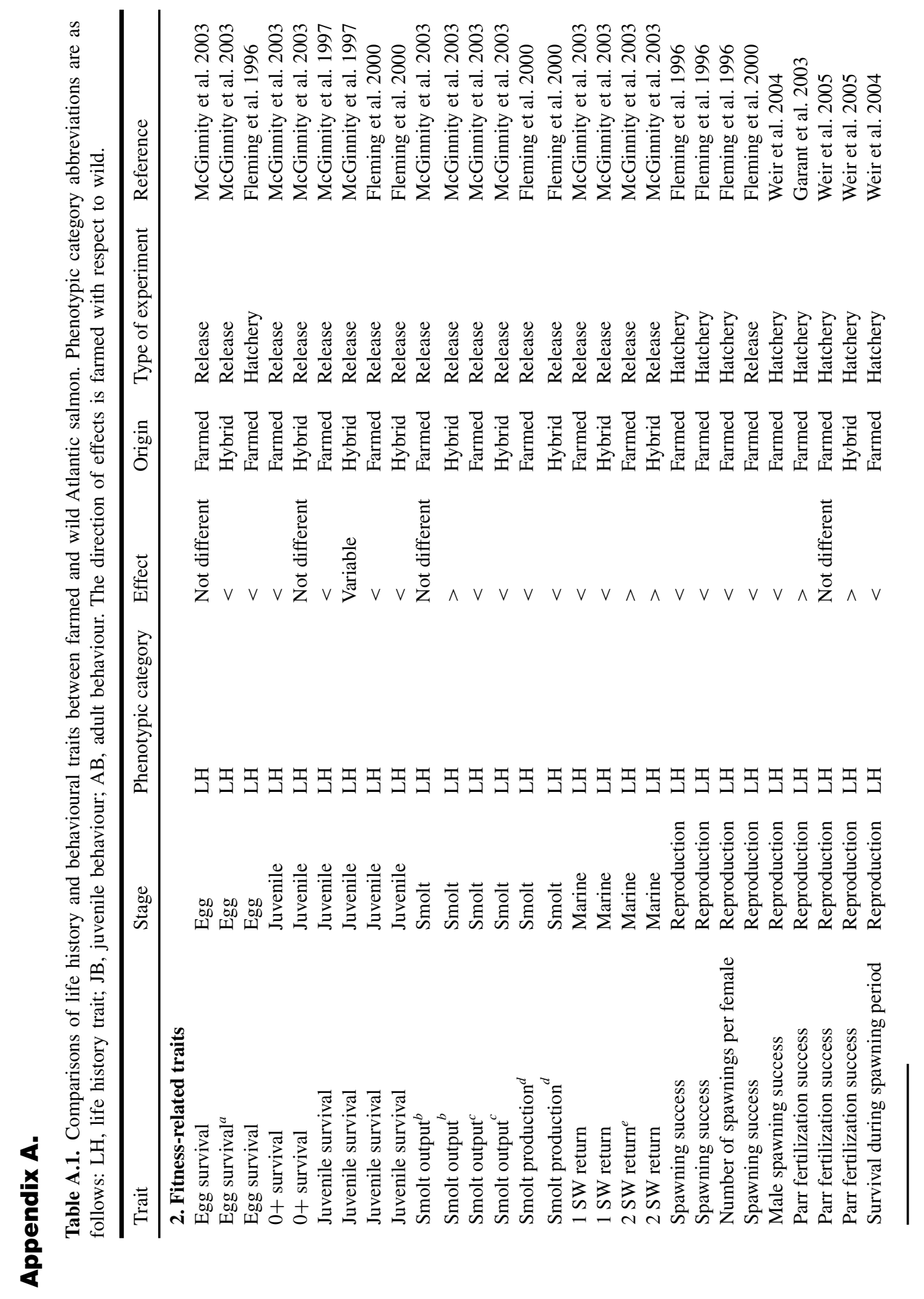

(C) 2005 NRC Canada 


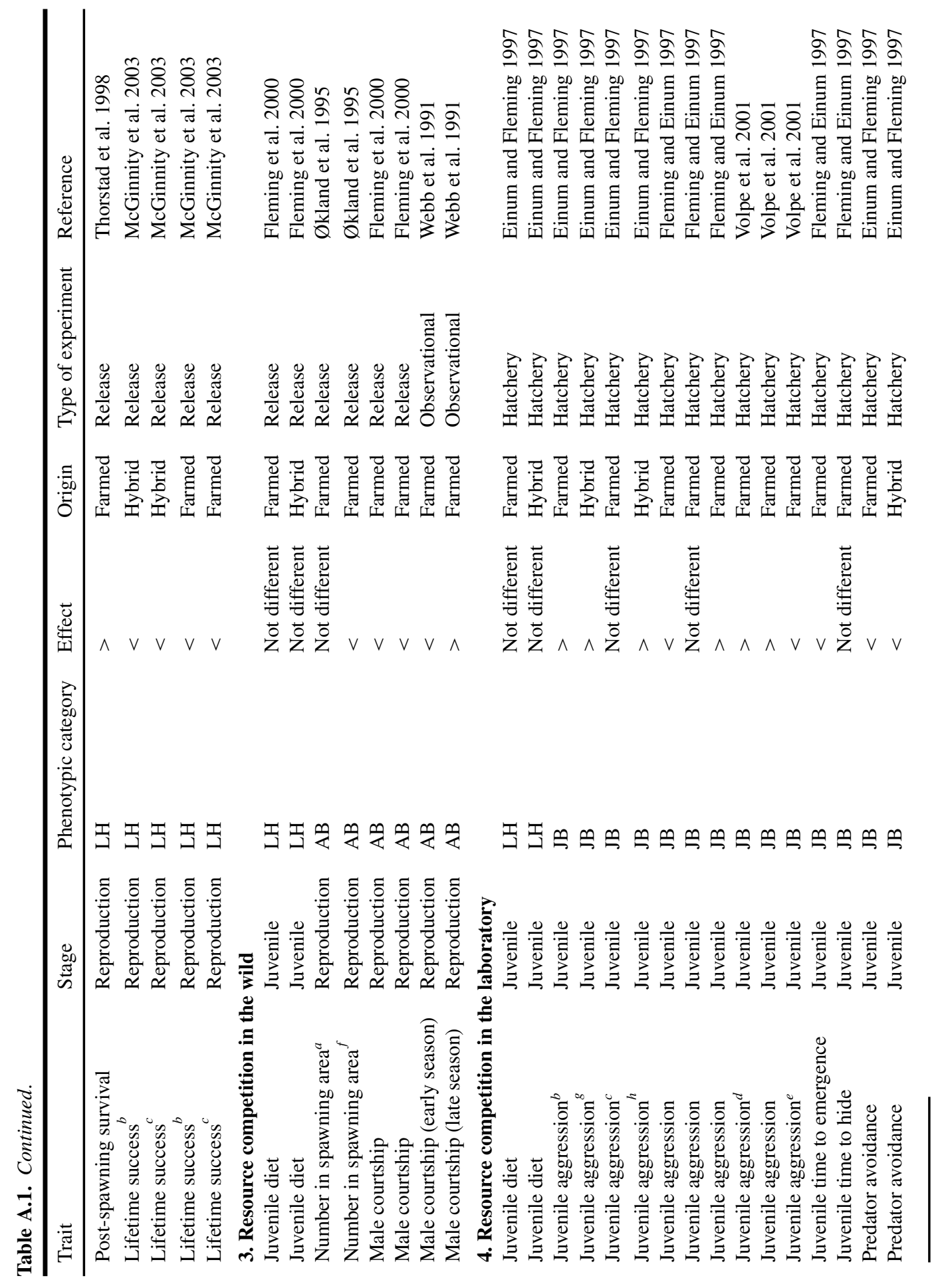




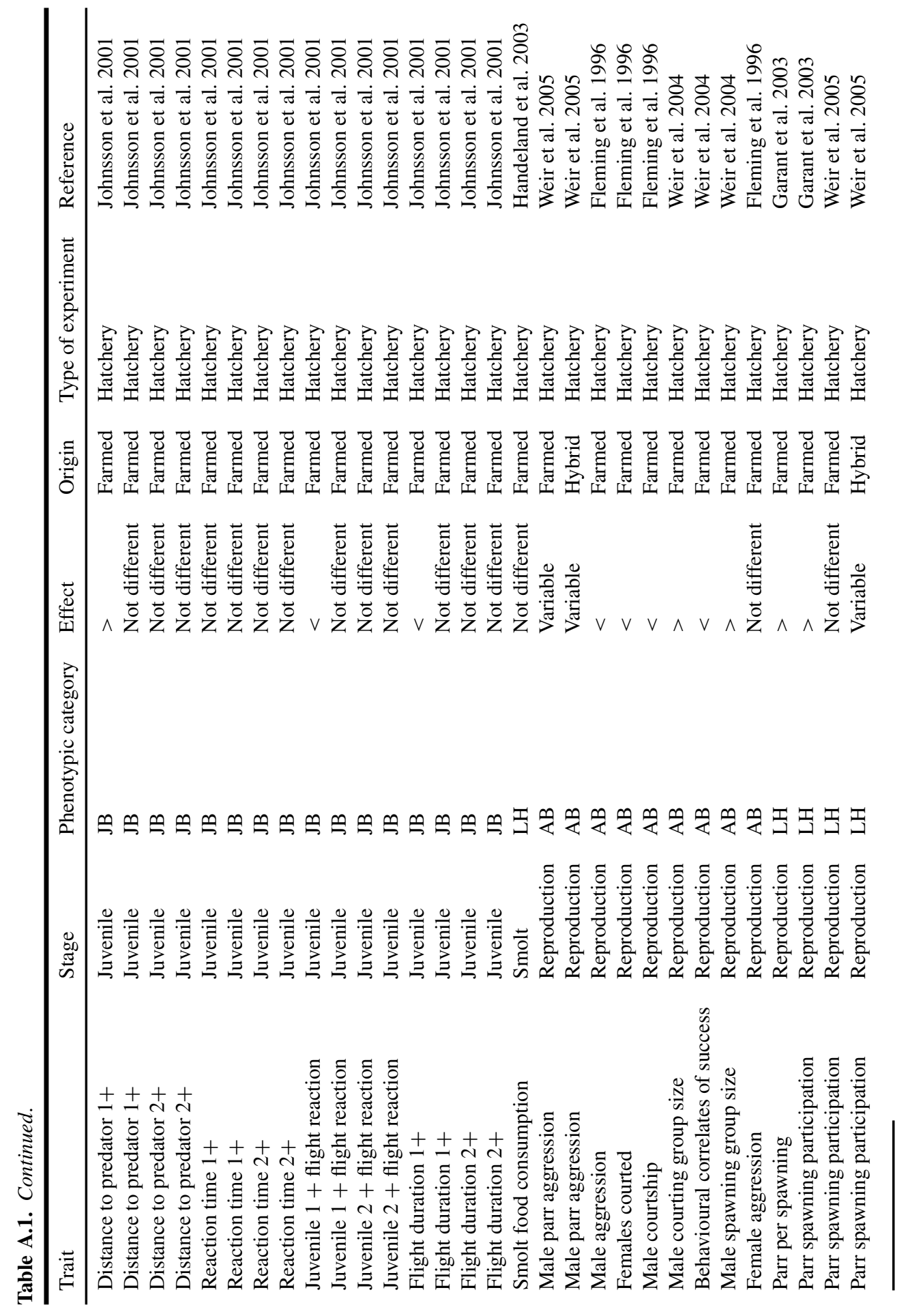




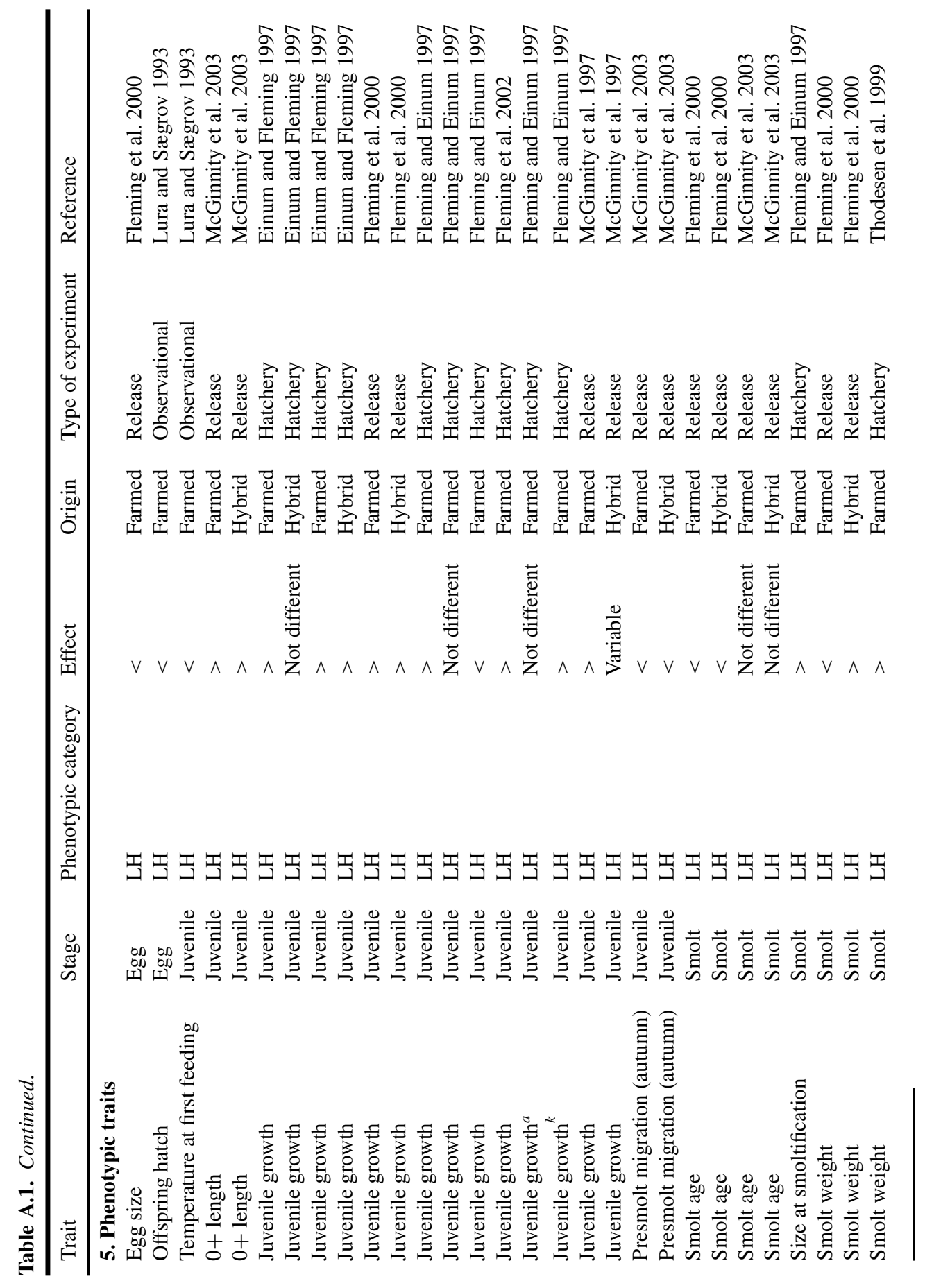




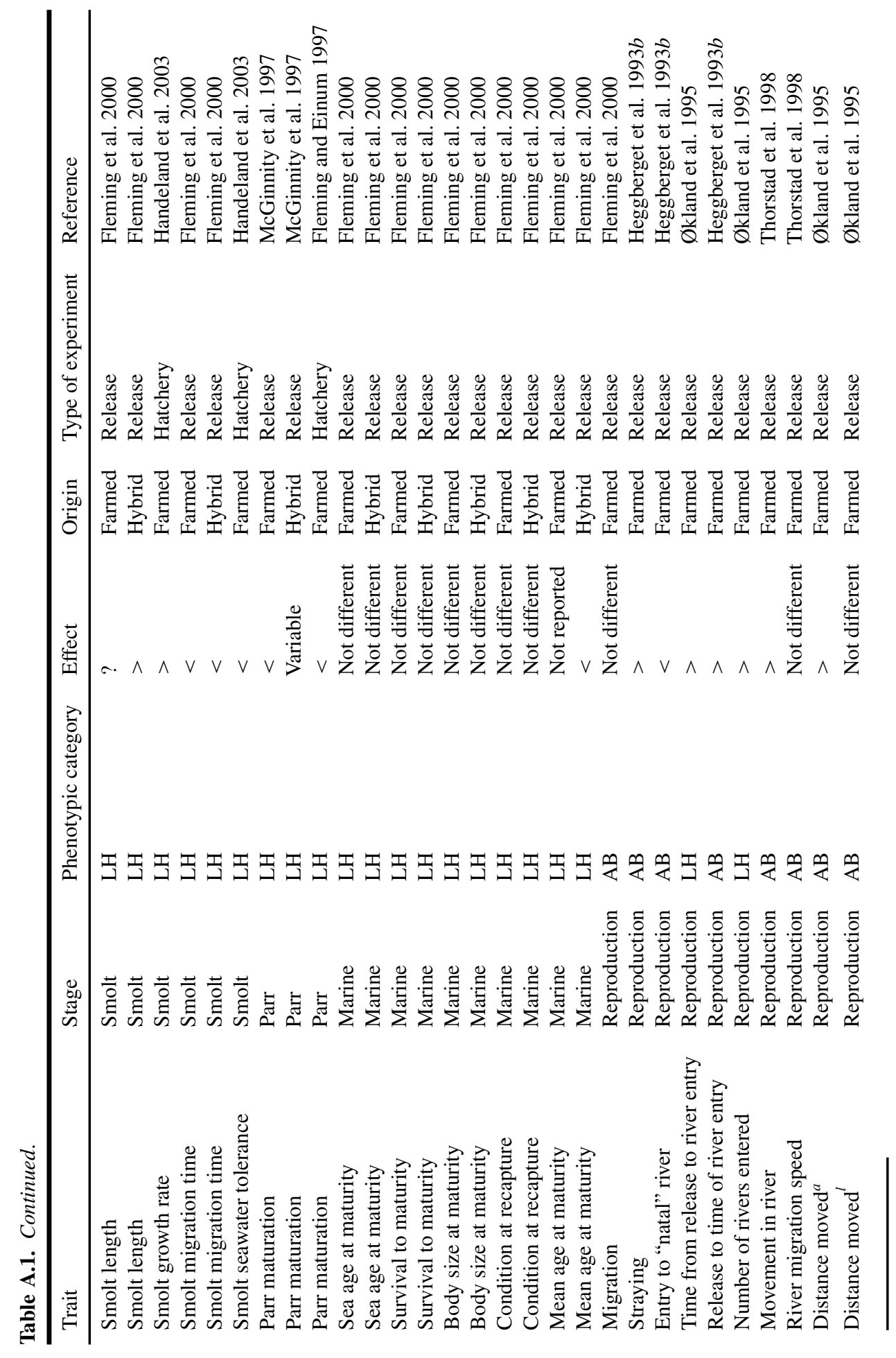




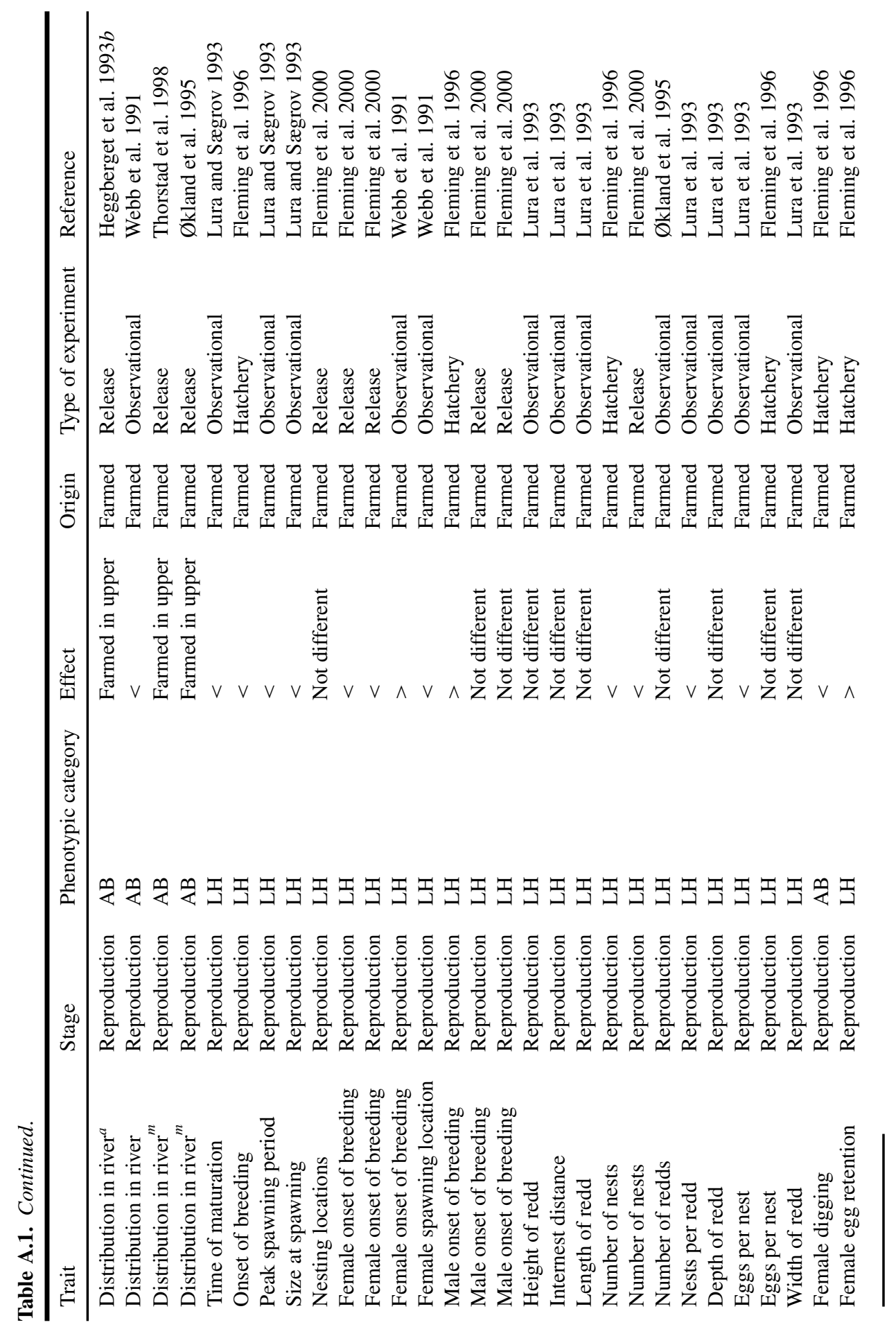




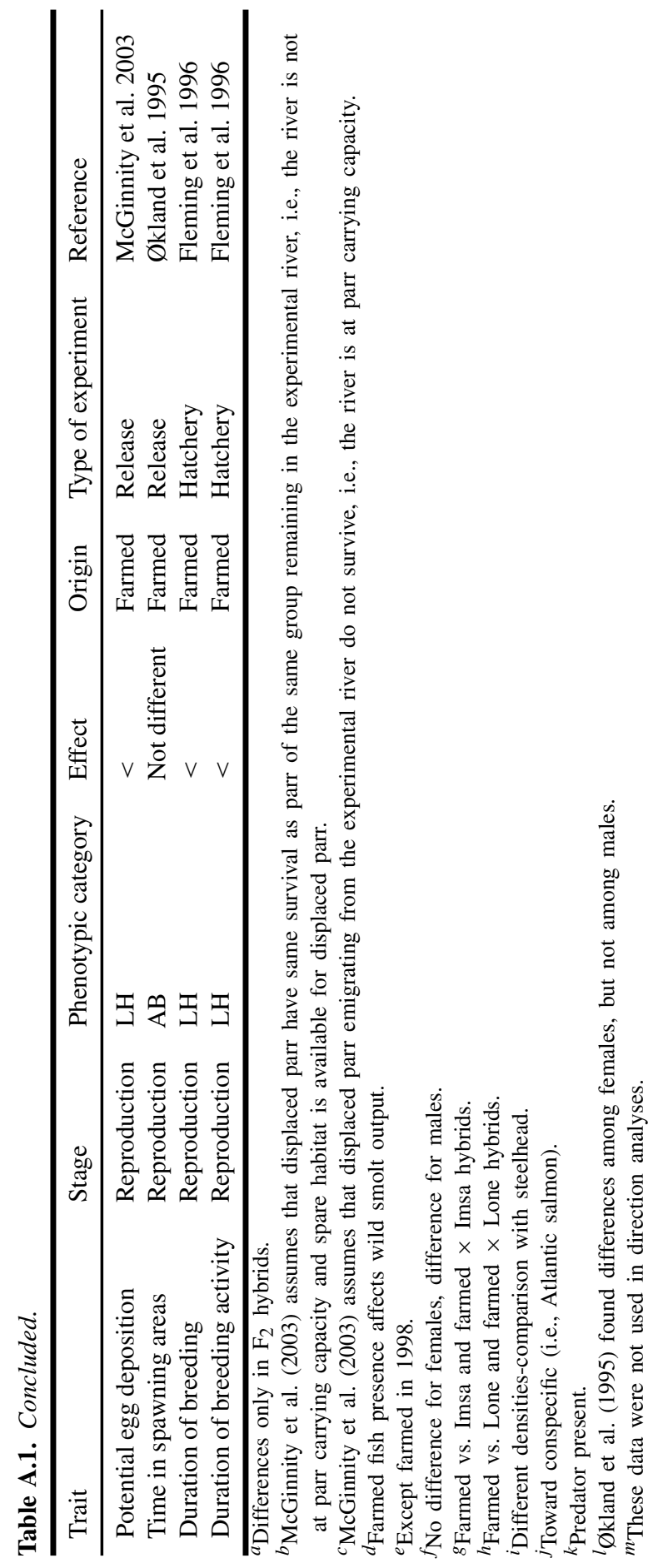

